\title{
THE LESUNG MUSIC IN THE VILLAGE OF LEDOK BLORA REGENCY
}

\author{
Suharto* \\ Siti Aesijah** \\ *Music Department, Semarang State University, \\ J1. Sekaran Campus Gunungpati Semarang, Indonesia \\ E-mail: harto1965@gmail.com \\ **Music Department, Semarang State University, \\ Jl. Sekaran Campus Gunungpati Semarang, Indonesia \\ E-mail: aesijahsiti@yahoo.com
}

Received: Januari 2013. Accepted: Februari 2014. Published: Maret 2014

\begin{abstract}
This research aims to identify in order to preserve traditional art lesung music in Blora Regency. This research use ethnomusicology approach. The subject of research is Blora people who still play lesung music as an expression of social and cultural activities in the community. The setting of the research took place in Ledok village. The technique of collecting data is observation and interview. The validity of data uses triangulation techniques. The data collected was analyzed with interactive type of Miles and Huberman. The result of research shows that the form of lesung music uses simple rhythms with elements of rhythm, melody, and harmony. Harmony in music is from the rhythmic beats of polyphonic arranged. This kind of music at first had any functions for the purposes of ritual, entertainment, welcoming guests, harvesting/offerings, a sign of the eclipse. Today, it serves as a means of musical entertainment at the village greeting, social interaction, and tourism. There is a shift of function due to the mindset of the people and the swift technology advances. Lesung music needs a modification in its presentation by adding songs and games. Another art element like dance can be added to make the show more interesting to be enjoyed.
\end{abstract}

(c) 2014 Sendratasik FBS UNNES

Keywords: lesung music; functions of arts; ethnomusicology

\section{INTRODUCTION}

The music of lesung is one of the traditional arts that flourishes along with the expression of gratitude over the bountiful rice harvest. This art with different terms can be found in various parts of the archipelago. The name adjusts of the local language, such as gejog lesung in Yogyakarta, kothekan lesung in Blora, ale tunjang in Aceh, etc.

The music of lesung is a traditional music with the instrument or tool of alu and lesung (Meita, 1992: 1-2). At first, this traditional art grew and thrived in the midst of agrarian societies since most of the people relied on agriculture for living. Pounding rice was a daily activity done by agricultural societies since it is the only way that could be used to separate rice grains from the chaff to be rice. While pounding rice, the people played music with lesung so that it produced music called lesung music, or music kothekan. It is called kothekan because it produces music that bleeps klotakklotek. 
In the past, the sound of lesung was heard when one of the residents had khajat (duwe gawe), such as mantu, mbesan (marriage), circumcision, kaul and others. The sound of lesung was beaten hard and continuously as a signal that khajatan would start. It was at the time shortly after pounding the rice to be the raw material of traditional food for local people jenang. Lesung could also be seen during the harvest season, when citizens together mashed the grain into rice

Heard from the distance, its voice was only "thok-thek-thok thok thek-thok$d u g^{\prime \prime}$. It was the sound of alu - a tool of wood shaped like a long stick, which strucks regularly against a big wood made like a boat called lesung. Nowadays, lesung is not used anymore to grind rice, but it is used as a traditional art that is usually played by women since once the grind rice with lesung was done by the women. The existence of lesung is still preserved as a traditional art. The art is in the alu's voice strucking against lesung sequentially. The lesung musicians are around five to six people. To reproduce the variations of setting, the sound of lesung can be combined with traditional songs, which are performed in a group. There is a group of people singing or nembang while dancing. There is also a group of dancing people, bending their body while certainly swirling as if dancing with complete Gamelan accompaniment.

Today, this traditional music is increasingly suffering more day; the extinction of the musical tradition in the era of cultural transformation of agricultural societies to the semi-industrial era is due to a lack of opportunity of this genre to exist as it used to be a part of the community supporters (Bramantyo, 2000: 103). Traditional music used to be a pride in the community; now begins to be abandoned.

According to Bramantyo, to revive and develop traditional music that owns a future perspective needs to be a formal transmission and an execution of largescale research programs in an integrated continuity. This process will encourage the world creation of art works with sophisticated techniques and simultaneously be followed the more reasonable aesthetical foundation as well.

The young generation leaves a traditional music that his ancestors owned for a long time due to their lack of understanding about the traditional music, particularly the meaning contained in it. They consider traditional music is an ancient or underdeveloped music that does not correspond to the period.

This circumstance is what happen to the existence of lesung music in the village of Ledok, a village located in Sambong, a part of Blora Regency. At the top of its fame, the music could only be played in certain places and certain times anyway. Lesung music that uses the lesung instrument that is approximately 3 to 4 meters in large has specific meanings and symbols from both the property and the type of play. Therefore, the reason of this certainty that lesung music played in certain places in the village was that the length of lesung symbolized the owner.

This music continued its existence along with the rice pounding activities and the rice consumption needs. Nevertheless, the music of lesung which is played by more than one person certainly has a specific function which makes the music survive in the decades, similarly with the instruments that are used, like a large lesung and alu. The result is a patterned music and the type of songs can be interpreted that the public has a sense of music in accordance with their musical experience.

It cannot be denied that technological advances, shifts in culture, and the concepts of social life due to the advances in information technology affect the existence of the music of lesung from time to time. The progress of the civilization of the Ledok villages in the way of rice producing ranging from planting rice to the final process of producing rice causes a fluctuation of lesung music condition. The younger generation has never watched this kind of music. It has been very rare to do such activity like rice pounding, to be replaceable 
by more modern grain grinder machines.

In 1985 Education and Culture Ministry conducted a research and recorded some lesung music in some areas in Indonesia; in Central Java and East Java the name is lesung, ale tunjang in Aceh, alu' galing in West Kalimantan, and the name of kareku kandei and kareku necu in West Nusa Tenggara. Furthermore, Astono (2002) studied on the background of music creation of lesung (from historical side), organology (viewed by the karawitan), the social cultural aspects (of the Javanese culture) with the focus of Lesung Banarata.

Aesijah's research (2007) on the symbolic meaning and expression of kotekan music in the village of Ledok illustrates that some of the functions of music has been left by the villagers. The function of the music like at the moment of sun or moon eclipse and offerings stated on the research are now difficult to find.

The existence of traditional music in Indonesia is on the wane. The existence of the traditional arts, including music that is usually embedded in social and cultural activities of the community began to disappear along with the loss of local social cultural activities were also abandoned. As a system, the function of art is not just in its use, but it ought to be explained as something which can be donated to a particular one in a system. The art is developed and standardized through social tradition arts of a society (Rohidi, 1993; Triyanto, 1993; Suparlan, 1983).

The purpose this paper writing is to present the result study, namely (1) ) the function of lesung music for social-cultural life of the Ledok society, and (2) musical concepts of existing lesung in the village of Ledok in the area of Sambong subdistrict Blora Regency.

\section{METHOD}

This research used a qualitative approach with textual and contextual study within the scope of ethnomusicology. The data collecting technique is an observation, interview, and document studies. The ana- lysis is using an interactive model of Milles and Huberman by not leaving the framework of ethnomusicology as its approach. The validity of the data uses the triangulation technique, from methods and sources.

Ethnomusicology is a research approach by understanding the concept of music from the creating community. The researcher is able to study how to feel, play, and express like the owner of the music does. The study of music in the context of culture according to Merriam (1964) known as the tripated model for the study of ethnomusicology could be examined from 3 levels, namely (1) the concepts about music, (2) the behaviour of music both from the players and the music connoisseur, and (3) the sound of the music itself. Thus, the study of ethnomusicology in this research is not out of these three aspects in analyzing the data.

\section{RESULTS AND DISCUSSION}

\section{Setting in Ledok Village}

Ledok village is a village in the area of Sambong subdistrict, Blora Regency. Its territory is divided into several sections, like forest, plantation, farms and settlements; with an area of approximately 10 $\mathrm{km} 2$. To reach the village, the transportation of a good four-wheeled vehicle or a motorcycle is mostly taken in a fairly good road condition.

The village is inhabited by 3392 people in 2013, most of who have an occupation as a farmer (287 people), peasants (163), civil servants (57) and many more. The interesting part of this is that most of the people get income from a traditional mining petroleum. This is derived from the mining wells as the legacy of Netherlands colonial in the land of Perhutani forests. Therefore, Ledok is actually a very rich village, especially in its potential of natural resources, from agriculture, forests to petroleum. Agriculture and plantation sectors produce approximately 50 hectares of sugar cane plants that is super in quality as an ingredient of making sugar. This plant is the result of the cooperation bet- 
ween the government of the village with the investors from outside of the region, and this sector has absorbed many labors both from within and outside of the region as well. From forestry sector, Ledok has good quality forests. Some consist of natural plants from the Ledok region, like kepoh, forest bamboo, adiantum, and tales. Every day in the paved streets of the village, Pertamina trucks pass carrying the good oils derived from the wells owned by Pertamina, or from the traditional miners.

\section{Art Life Archives}

Recently, some groups of music, like karawitan, keroncong, solo organ, and tayub are emerging. Among those kinds of music, karawitan is the most favorable; then, solo organ is in the second place. These two kinds of music are exist since it is still considered to be functional and readily accepted in all social strata and age, and in the social life of their culture, while the music of lesung is played by older generation that the average age is over 65 , and the number of players is decreasing. The moment of performing is only to commemorate certain events, such as welcoming special guests, the activity of clean village (bersih desa), the independence day, the invitation to the district, or subdistrict, while daily artistic activities unfortunately are not held.

The life of art that used to be lesung music, or acoustic karawitan has never been heard faintly again. The most prominent one is the sound of electronic music from the loudspeakers in the celebration at the corners of the village.

\section{The functions of lesung music for the life of the Ledok villagers}

The function of art is divided into six sections, namely the function of personal, society (social), physical, religious, education, and economic (Setiawan, 2012). In Ledok community, lesung music currently no longer serves as a means of religious or ritual both personal and social. The utilization of music performance is more spontaneous as a special guest welcoming. An offering ceremony to Dewi Sri, or Sedekah Bumi, at the time of the procession and live music performance would rather use $b a-$ rong, or kuda kepang. Lesung music is rarely used for offerings in traditional oil drilling anymore.

The performance of lesung music is far from the social life, and only involves a very limited group of society and not binding. It means this lesung music no longer belongs to a cultural system of the village community of Ledok anymore. Once, in any social event, or entertainment always poses such lesung music, like at the moment of sun or moon eclipse, offerings, entertainment to release tiredness after rice pounding, and codes of such events that are occuring in the village. It means without lesung music, all social cultural activities of the village community of Ledok keep running normally. Thus, the music of lesung, which incidentally is already difficult to find both musical instruments (lesung) and the performance, is no longer a part of the cultural system that is important to the people. As a system, the function of art is not just in its use, but it ought to be explained as something which can be donated to a particular one in a system. The art is developed and standardized through social tradition arts of a society (Parsons, 1951; Rondhi, 2002; Triyanto, 1994; Rohidi, 1993).

Thus, the existence of lesung music will gradually be extinct by itself if the lesung music is considered inessential and no longer relevant to the life of the community supporters. This situation has been going on in other rural areas in Blora Regency, in which the difficulty of finding lesung equipment almost owned by middleclass people is also such a problem. This situation is already caused by the function of nutu (pounding the rice) traditionally turning to rice mill machine which is considered more efficient and cheaper. Not only that, the technology of modern arts, like solo organ, takes any part to push the existence of lesung music down.

The existence of the group of lesung music founded by Sisworo, a public rela- 
tion of Cepu International Heritage Club (CIHC) in the village of Ledok is concerned. Six players of lesung have been very old, and two members that usually play music suffer from stroke. The efforts of cultural inheritance is running very slow. In addition, the difficulties of transferring knowledge and skill of the old players, and lack of the interest of the young generation toward this kind of music bring the existence in a bad situation.

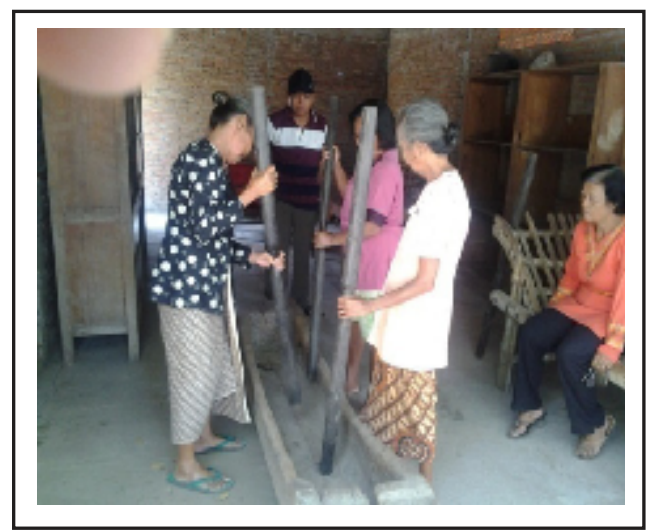

Figure 1. Lesung Players at Ledok

The Musicality of Lesung Music in the Village of Ledok

The number of players of the group and the name of lesung music players have not changed for decades causing the game character and musicality of his music has not changed. Moreover, they are the older generation who had never attended special education namely music. Minimal musical experience of the players cause the game patterns, melodies and harmonies are very limited. Western diatonic musical influences are virtually untouched by them.

The music of lesung is a kind of music performance with main instruments of lesung and alu/antan. The performance in the village of Ledok is shown by 3 to 4 people playing lesung. This art is very simple both in musical forms and the appearance of players, but the sound resulted from the lesung pounded is quite beautiful.

Unfortunately, the simplicity of this music does not interest the younger generation to learn. The younger generation is more interested in modern music types that are considered more attractive. Lesung music is considered outdated and does not meet their artistic needs him this global era.

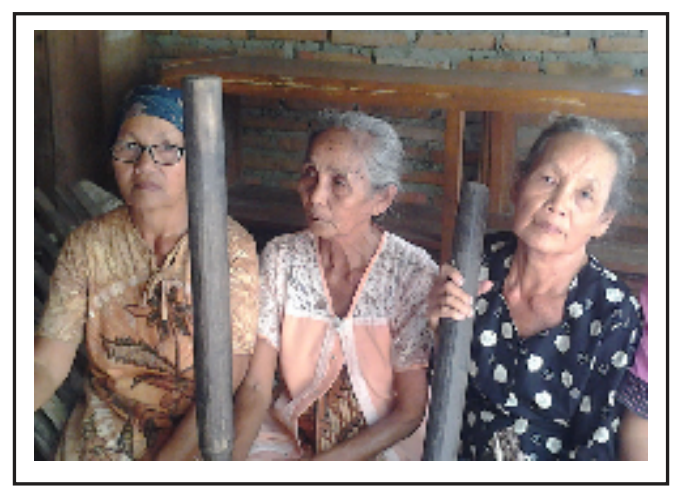

Figure 2. Three Lesung Players from Village of Ledok

Rhythm

Some patterns of rhythm that is played are Kang Nganten, Sekar Lempang, and Bluluk Ceblok. The examples of rhythm pattern can be seen in the Figure 3, Figure 4 and Figure 5.

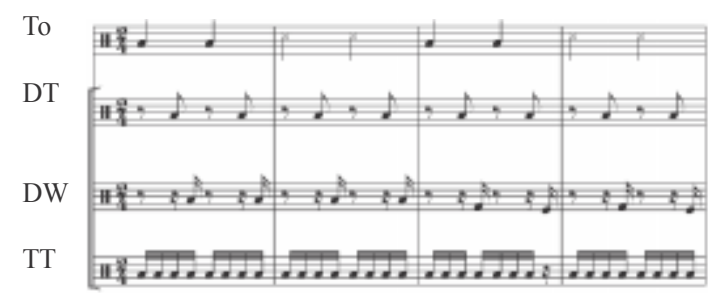

Figure 3. Rhythm Pattern of Kang Nganten

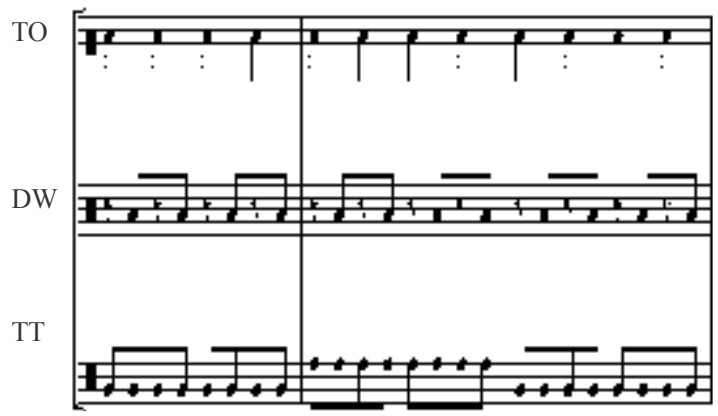

Figure 4. Rhythm Pattern of Sekar Lempang 


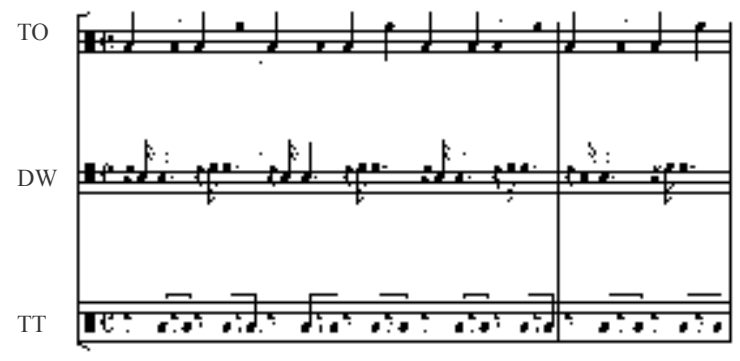

Figure 5. Rhythm Pattern of Bluluk Ceblok

Notes:

TO: Tunggu Omah

DT: Duduk Tengah

DW: Duduk Wingking

TT: Titir

Rhythm patterns such as Kang Nganten, Bluluk Ceblok, Sekar Lempang are always played from time to time without changing any variation. However, actually the rhythm patterns is exist with the background creation of each process. In addition, the background also has a specific meaning although the meaning is no longer considered important to the people's lives. Meaning that it became symbols that does not fully apply to social and cultural life of the village community Ledok

The complementarities of life are manifested in their play. The types of players with musical parts such as Tunggu Omah, Duduk Tengah, Duduk Wingking, and Titir are examples of parts of the music performance. In Javanese culture concept in the village of Ledok, functions of the family members is very important in maintaining family harmony. If any of them deviate the family life will be disrupted. It is the symbolic meaning in the lesung music game in the village.

\section{Melody and Harmony}

Melody played in the music of lesung is simply a short introduction of the lesung with a vowel sound. An examples of a melody below that serves as bowo are Kang Nganten and Sekar Lempang.
In the definition of diatonic music, harmony is called sound adjustment caused by the combination of tones in a certain size that sound together. According to Banoe (2003: 180), harmony relates closely to chord. In the music of lesung the harmony is in the rhythm without tones. If so, the sound harmony is actually caused by the shift of the intensity of the sound, not tones, while the frequencies are dealing with the tones. A tone has the size of frequency measured how much vibration or wave within a second.

Kang Nganten and Sekar Lempang are examples of simple songs that are always played them since decades. The songs use a Javanese pentatonic scale. They are generally just simple songs as an introduction (bowo), then they continue to play an ostinato in accordance with the rhythm pattern name. Once again, the game will stop until the collision of rhythm is occurred (tumbuk).

\section{CONCLUSIONS}

Recently, lesung music in the village of Ledok is no longer a cultural system that affect the social cultural life of the society. This is due to the function of lesung music that originally functioned as a part of social cultural life of the society, such as merti desa, a sign of eclipse, a signal of significant events, entertainment in commemoration of the important days, now turning to limited use. The Lesung performances nowadays are only for incidental ceremonial occasions.

The performance of lesung music is considered old-fashioned for the young generation since the musical system is very simple. This simplicity makes the young generation is reluctant to learn it for there is an electronic music that becomes more interesting. In addition, the mindset of people has turned to leave the ritual functions, such as a sign of solar eclipses, a sig- 
nal to call people, and marriage.

The potential is that the village has become the 'brand' of the existence of lesung music although the existence was not the same as two decades ago. Lesung music is recently only presented in certain events, such as the visits of foreign travelers and the performances requested by local, district, or subdistrict governments.

Both village and district governments need to attempt mainly through education, in the elementary schools and formal educations. This effort needs to be realized due to the lack of interest of young generation to this kind of music, remembering that the number of players is constantly descreasing. The inheritance pattern through formal educations, especially in elementary school, needs to be done with the adjustment of the size of alu to be easy to use for elementary school students. Besides it, the various patterns of performance ought to be observed. It can be combined with other types of art, such as dance.

\section{REFERENCES}

Aesijah, S. (2007). Makna Simbolik dan Ekspresi Musik Kotekan. Harmonia Jurnal Pengetahuan dan Pemikiran Seni. 8(3): 225-232

Astono, S. (2002). Lesung Banarata Karawitan di Akar Rumput. Keteg Jurnal Pengetahuan-Pemikiran \& Kajian tentang Bunyi. 2(1)

Banoe, P. (2003). Pengantar Ilmu Harmoni. Salatiga: Kanisius

Bramantyo, T. (2000). Revitalisasi Musik Tradisi dan Masa Depan. Mencari Ruang Hidup Seni Tradisi (103107). Yogyakarta: BP Fasper ISI and Yayasan untuk Indonesia.

Bergerf, A. A. (2010). Signs in Contemporary Culture: An Introduction to Semoitics Translated by Dwi Satrianto. Yogyakarta: Tiara Wacana.
Departemen Pendidikan dan Kebudayaan. (1985). Ensiklopedi Musik Indonesia A-E. Jakarta : Peroyek Penelitian dan Pencatatan Daerah.

Koentjaraningrat. (1984). Kebudayaan Jawa. Jakarta: PT. Balai Pustaka.

Koentjaraningrat. (2000). Kebudayaan

Mentalitas dan

Pembangunan. Jakarta: PT. Gramedia Pustaka Utama.

Mills \& Huberman. (1992). Analisis Data Kualitatif. Translated by Tjetjep Rohendi Rohidi. Jakarta : UI Press.

Merriam, A.P. (1964). The Antropology of Music. Bloomington: Norhwestern University Press.

Meita. (1992). Kothekan Lesung Karanganyar. Retrieved http://digilib.uns. ac.id/1992.html. June 13, 2013.

Muiz, A. (2005, Mei 14). Lesung Disuguhkan Lantaran Keunikannya. Suara Merdeka 24, 2.

Rahmanto, B. (1992). Simbolisme dalam Seni. Yogyakarta: BASIS, Jawanisasi Kebudayaan Indonesia.

Rohidi, T.R. (1994). Pendekatan Sistem Sosial Budaya dalam Pendidikan. Semarang: IKIP Press.

Rosjid, A. (1979). Seni Tari III. Jakarta: Aqua Press.

Sedyawati, E. (1981). Pertumbuhan Seni Pertunjukan. Jakarta: PT. Djaya Pirusa.

Sudiarja, A. (1982). Manusia dalam Dimensi Simbol dalam Manusia Multi Dimensi. Jakarta: Gramedia.

Suparlan, P. (1983). Manusia, Kebudayaan, dan Lingkungannya: Perspektif Antropologi“. Manusia dalam Keserasian Lingkungan. Jakarta: Lembaga Penerbit Fakultas Ekonomi UI Jakarta.

Triyanto. (1993). Pendidikan Seni sebagai Proses Enkulturasi Nilai-nilai Budaya. Jurnal Media 16(4) 211-221.

Wibowo, F. (2000). Seni Tradisi di Tengah Kemajuan Teknologi Tinggi. Ekspresi 2(1) 57-64. 